\title{
The Effects Of Lucilia Sericata Larval Secretions On The Expressions Of microRNAs That Are Suggested To Be Related With Wound Healing In Experimental Diabetic Rat Wound Model
}

\author{
Deneysel Diyabetik Sıçan Yara Modelinde Lucilia sericata Larva salgılarının \\ Yara İyileşme Süreci ile iliş̧kilendirilmiş MikroRNA'ların Ekspresyon Seviyeleri \\ Üzerine Etkisi
}

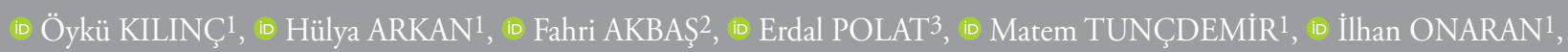

(i) Ahmet ÖZAYDIN 1

1'̇stanbul University-Cerrahpaşa Cerrahpaşa Faculty of medicine, Department of Medical Biology, İstanbul, Turkey

${ }^{2}$ Bezmialem Vakıf Univeristy Faculty of Medicine, Department of Medical Biology, İstanbul, Turkey

3̇̇stanbul Üniversitesi-Cerrahpaşa Cerahpaşa Faculty of MedicineDepartment of Microbiology and Clinical Microbiology, İstanbul, Turkey

\section{ABSTRACT}

Objective: Normal wound healing is achieved by a cascade of many cellular activities. This process is affected by some of the metabolic diseases like Diabetes mellitus (DM). DM causes bad prognosis and is one of the major contributors to chronic wound healing problems. Recently, Lucilia sericata larvae are used for wound healing as they are very effective agents in wound healing process. It's still unclear that how the larvae affect the molecular mechanisms and signaling pathways of chronic wound healing. microRNAs can induce gene expression in posttranscriptional mechanisms. In this study, our aim was to determine whether the larvae secretions could change the expression patterns of selected miRNAs on the diabetic microenvironment wounds or not.

Methods: Wistar Albino rats were classified as diabetic and nondiabetic, then full thickness cutaneous wounds created at the dorsal region of rats. Wound tissues were collected on days $0,3,7$ and 14 post wounding. The association between miR21, miR146a, miR146b and miR29a gene expression profiles and wound healing process was investigated by using Real Time PCR method.

\section{Öz}

Amaç: Normal yara iyileşmesi bir çok hücresel faaliyetin zincirleme tepkimeleri ile gerçekleşmektedir. Diabetes mellitus gibi metabolik hastalığa sahip kişilerde ise bu süreç olumsuz etkilenmekte, kötü iyileşen ya da iyileşmeyen kronik yaraların meydana gelmesine neden olmaktadır. Lucilia sericata larvalarının yara iyileşmesinde etkin rol oynamakta olduğu bildirilmiştir ancak kronik yara iyileşmesinin moleküler mekanizmasında ve ilgili yolaklardaki etkileri hala bilinmemektedir. RNA türlerinden biri olan mikroRNA (miRNA)'ların bir bölümünün yüksek glukoz düzeylerinde ekspresyonlarının değiştiği gösterilmiştir transkripsiyon sonrası gen düzenlenmesini indükleme yeteneğine sahip olduğu bildirilmektedir. Bu sebeple çalışmamızda; yara iyileştirmesinde rolü olduğu bildirilen bazı miRNA'ların ekspresyonlarının diyabetik şartlarda larva salgısı uygulaması ile deri iyileşmesi süresince ne yönde etkilendiği incelenmiştir. diyabetik yaralardaki miRNA'ların ekspresyonunu değiştirip değiştirmediğinin belirlenmesi amaçlanmıştır.

Yöntemler: Deneysel çalışmamızda kullanılan Wistar Albino türü sıçanlar diyabetik ve diyabetik olmayanlar olarak gruplandırıldıktan sonra sırt bölgesinde tam kat yara oluşturulmuştur. Oluşturulan yara bölgelerinden 0., 3., 7. ve 14. günlerde biyopsi örneği alınmıştır.
Address for Correspondence/Yazışma Adresi: Ahmet ÖZAYDIN, İstanbul University-Cerrahpaşa Cerrahpaşa Faculty of medicine, Department of Medical Biology, İstanbul, Turkey E-mail: aozaydin@istanbul.edu.tr ORCID ID: orcid.org/0000-0003-3959-3053
Received: 08.01.2018

Accepted: 19.03.2019 
Results: The increase in expression of miR21 gene in diabetics treatment group was seen most on 3rd day according to diabetics control group. An increase in expression profiles of miR146a, miR146b and miR29 genes was seen most in larval treatment group according to diabetics control group.

Conclusion: Our results have shown that larval secretion in wounds formed in diabetic rats affects the expression of miRNAs associated with wound healing process. Larval secretion therapy has been shown to increase wound healing and reduce inflammatory response by altering the expression of miR146a in diabetics

Keywords: Normal Wound Healing, Diabetic Wound Healing, Maggot Debridement Therapy, Lucilia sericata, MicroRNA expression.
Çalışmamızda literatür taraması yapılarak yara iyileşmesi ile ilişkilendirilmiş miR21, miR146a, miR146b ve miR29a genlerinin ifade analizleri, gerçek zamanlı PZR ile değerlendirilmiştir.

Bulgular: miR21 geninin diyabetik kontrole göre diyabetik tedavi grubundaki ifade artışı en fazla 3. günde görülürken, miR146b, miR146a ve miR29a genlerindeki ifade artışı diyabetik kontrol grubuna göre kıyaslandığında en fazla larva salgısı tedavisi uygulanan gruplarda olduğu görülmüş̧ür.

Sonuç: Sonuçlarımız ile diyabetik sıçanlarda oluşturulmuş yaralarda larva salgısının yara iyileşme süreci ile ilişkilendirilmiş miRNA'ların ifadelerini etkilediği bulgulanmıştır. Larva salgısı tedavisinin diyabetiklerde miR146a'nın ifadesini değiştirerek yara iyileştirmesini arttırdığı ve inflamatuar yanıtı azalttığı gösterilmiştir.

Anahtar Sözcükler: Normal Yara İyileşmesi, Diyabetik Yara İyileşmesi, Larva Debridman Tedavisi, Lucilia sericata, MikroRNA Ekspresyonu

\section{Introduction}

Although inadequate wound healing in diabetic patients is not fully understood, several studies in various diabetic human and animal models have shown that some disruptions have occurred in various stages of the wound healing process. It has been shown that the diabetic microenvironment significantly affects keratinocyte and fibroblast functions, and can alter extracellular matrix (ECM) structure and function (1-3).

Matrix metalloproteinases (MMPs), keratinocyte and fibroblast functions are impaired, collagen synthesis is delayed, and fibroblasts are unable to produce sufficient amount of extracellular matrix. in diabetes (1). MicroRNAs, known as small non-coding RNAs, are single-stranded RNA molecules that act negatively on genes at the translational level. In various studies, it has been observed that the release of cytokines and interleukins in chronic wounds contributed to various molecular stages such as angiogenesis and cell proliferation (4-6). The wound healing is delayed as a result of the negative factors that occur in the healing process of chronic wounds. Treatments applied to shorten this process are effective. The studies revealed that larval secretion treatment is succesful in debridement of chronic wounds $(7,8)$.

Considering that miRNAs are required for the various phases of chronic wound healing and that miRNA levels change as a result of various treatments that accelerate chronic wound healing, larval secretions can affect miRNAs during the period of accelerating healing by affecting the various phases of diabetic wound healing in diabetic microenvironment (9). However, there is no study concerning the effect of larval secretions on the expression of miRNAs associated with wound healing in diabetic subjects wounds. In our study; it is predicted that the expression of miRNAs associated with wound healing may also change. For this reason, we aimed to determine whether or not Lucilia sericata larval secretions are changing the expression of four miRNAs, miR21, miR146a, miR146b and miR29a, which were shown to have a critical potential in effective healing by bioinformatics studies (10). that we specify and choose earlier as associated with wound healing. in diabetic wounds.

\section{Methods}

\section{Animal Experiments and Tissue Preparation}

In our study, 20 male Wistar Albino rats weighing 300-350 gr were obtained. Male rats were preferred in our study, as processes such as breeding period, birth, nursing care, lactation duration in the female rats would affect the results of the experiment. Our study was approved by the Istanbul University Animal Experiments Ethics Committee. Decision no: 2013/44. Under standard conditions, the rats were provided with free access to water and food, and 4 groups of 5 animals were separated. The first two groups were separated into treatment groups while the other two groups were divided into control groups. Preexperimentally, the rats were fasted overnight and were injected intraperitoneally with $60 \mathrm{mg} / \mathrm{kg}$ streptozotocin (STZ), $\mathrm{pH}=$ 4.5 in $0.1 \mathrm{M}$ citrate buffer, to form diabetes. Diabetes mellitus formation was checked 3 days after the injection of streptozotocin by measuring the blood glucose level in the rat's tail vein. Those with blood glucose levels above $250 \mathrm{mg} / \mathrm{dl}$ were considered diabetic and included in the study $(11,12)$. The rats to be used in the experiment were anesthetized with intraperitoneal (i.p.) Pental sodium (Pentobarbitone sodium) (IU Ulgay Medicine Industry Co. Inc., Istanbul, Turkey) at $40 \mathrm{mg} / \mathrm{kg}$ and then dorsal fur was shaved. The biopsy 'Punch' tool was used to create a full-layer excisional wound model with four $12 \mathrm{~mm}$ diameters of epidermis and dermis at equal distances of about $1 \mathrm{~cm}$ each on each dorsal thoracic region. The day of wound formation was accepted as day 0. Both PBS and larval secretions were absorbed into the surgical sponges and placed on the wound. Biopsy materials were taken on the $3^{\text {rd }}, 7^{\text {th }}$ and $14^{\text {th }}$ days after the wound was formed. Tissue fragments were homogenized with a homogenizer (Next advance, USA) by placing $500 \mu \mathrm{l}$ of Qiazol lysis buffer (Qiagen, USA) and 3 times of tissue weight of zirconium beads (Next advance, USA) for use in RNA isolation method and kept at $-80^{\circ} \mathrm{C}$.

\section{Real-time PCR (RT-PCR)}

After isolation of the RNA from the homogenized tissue, the purity and quantity of the samples were measured on a nanodrop 
spectrophotometer. Following cDNA synthesis were used for Real Time PCR procedures to detect the expression levels of miRNAs that previously associated with wound healing. In our study, four genes that were found to be effective in the wound healing process by literature review, identified as miR21, mir29a, mir 146a, mir146b. A real-time PCR run was made for each of the $70 \mathrm{cDNA}$ samples, repeated 2 times. Inconsistent results were not evaluated. Coefficients calculated by the $2-\Delta \Delta \mathrm{CT}$ method, and values less than 2 and greater than -2 considered to be insignificant.

\section{Results}

Results from biopsy samples taken at days $0,3,7$, and 14 of wound healing were evaluated separately for miR21, miR146a, miR29a and miR146b genes. For the $3^{\text {rd }}, 7^{\text {th }}$ and $14^{\text {th }}$ days, fold changes of the treatment group according to the control group were calculated in both diabetic and normal groups (Figure 1).

According to the findings obtained by real-time PCR study, fold changes of miR146a, miR21, miR29a and miR146b genes in diabetic rat skins compared to normal rat skins were examined separately on day 0 skin samples. Accordingly, expression of miR146a gene decreased 3.75 fold, miR29a gene decreased 4.43 fold, miR21 gene decreased 9.37 fold, and miR146b gene decreased 12.57 fold in diabetic group compared to normal group. When four genes are compared among themselves, it is

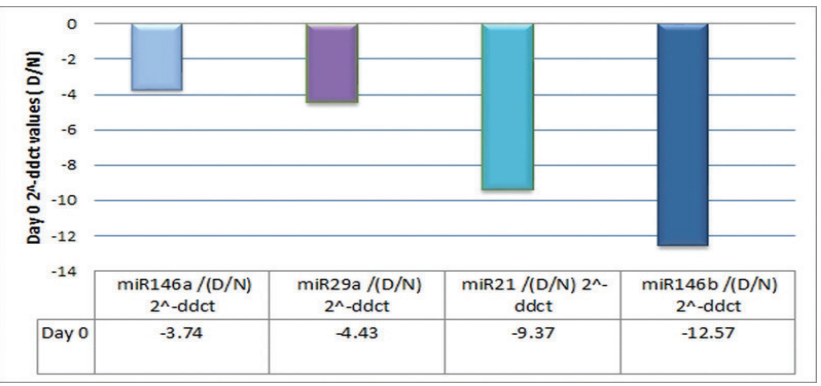

Figure 1: Representation of miR146a, miR146b, miR21, and miR29a gene expression changes in the diabetic skin relative to the normal skin. Expressions of related genes are shown as fold change

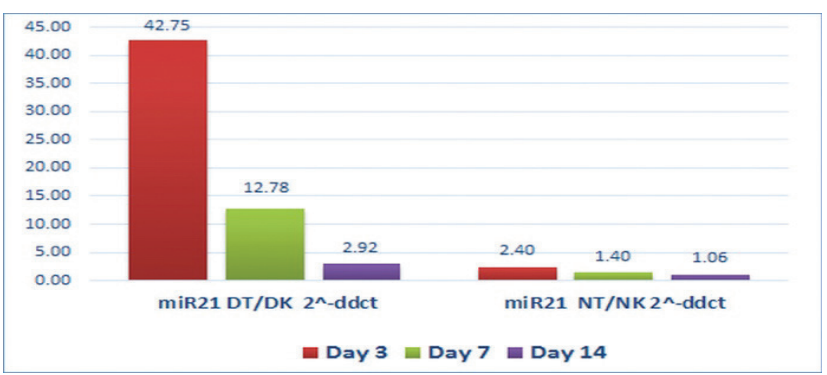

Figure 2: Evaluation of expression changes of the miR21 gene in the larval secretion applied wound tissues on $3^{\text {rd }}, 7^{\text {th }}$ and $14^{\text {th }}$ days, compared to the control group. Expression of the genes involved is shown as fold change, and diabetic and normal groups are evaluated within themselves seen that fold change value is at most $146 \mathrm{~b}$ gene (Figure 2).

The expression of miR 21 gene in the $3^{\text {rd }}$ day is 42,75 fold increase in diabetic therapy group (DT) according to diabetic control group (DC) whereas it is seen as 12,78 on the $7^{\text {th }}$ day. In the DT group, the miR 21 expression increased 2.92-fold over the DC group on the $14^{\text {th }}$ day. In the healthy group, the expression of miR2 1 in the $3^{\text {rd }}$ day was 2.40 fold higher in the normal therapy group (NT) than in the normal control group (NC), whereas it was 1.40 in the $7^{\text {th }}$ day and 1,06 times in the $14^{\text {th }}$ day (Figure 3).

While the miR146a gene showed a 9.79-fold increase in DT compared to the DC group on the $3^{\text {rd }}$ day, it increased to 4.11 fold on the $7^{\text {th }}$ day. The DT group showed a 7.45 -fold increase in expression of miR146a on day 14 compared to the DC group. In the diabetic group, it was seen that the increase of folds was the most at $3^{\text {rd }}$ day, while the least at $7^{\text {th }}$ day when the 3,7 and 14 days were compared within themselves. In the healthy group, the expression of miR146a gene in the $3^{\text {rd }}$ day was 3.19 fold the expression of the $146 \mathrm{a}$ gene on the $7^{\text {th }}$ day decreased by 1.51 times in NT compared to the NC group, but decreased by 4.22 times on the $14^{\text {th }}$ day. When the days 3,7 and 14 were evaluated in the normal group, it was seen that the expression of miR146a showed the highest increase on the third day (Figure 4).

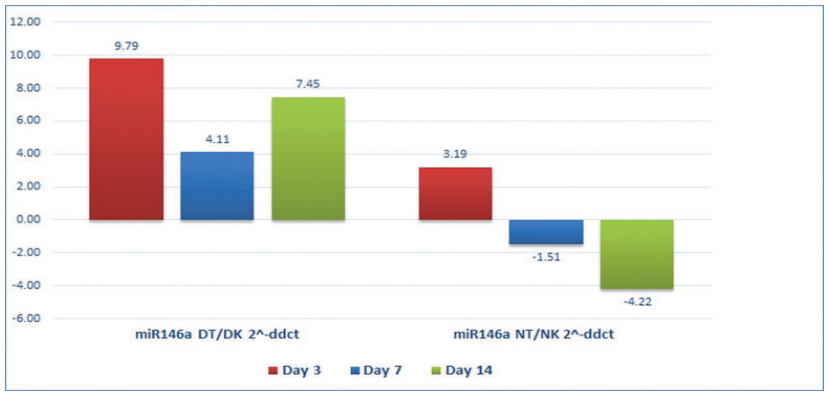

Figure 3: Evaluation of expression change of miR146a gene in the larval secretion applied wound tissue on the $3^{\text {rd }}, 7^{\text {th }}$ and $14^{\text {th }}$ days, compared to the control group. Expression of related genes is shown as fold change, and diabetic and normal groups are evaluated within themselves

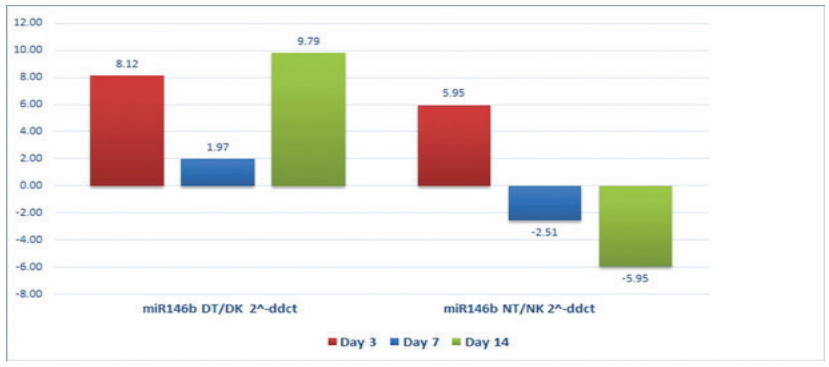

Figure 4: Evaluation of expression change of miR146b gene in the larval secretion applied wound tissue on the $3^{\text {rd }}, 7^{\text {th }}$ and $14^{\text {th }}$ days, compared to the control group. Expression of related genes is shown as fold change, and diabetic and normal groups are evaluated within themselves 


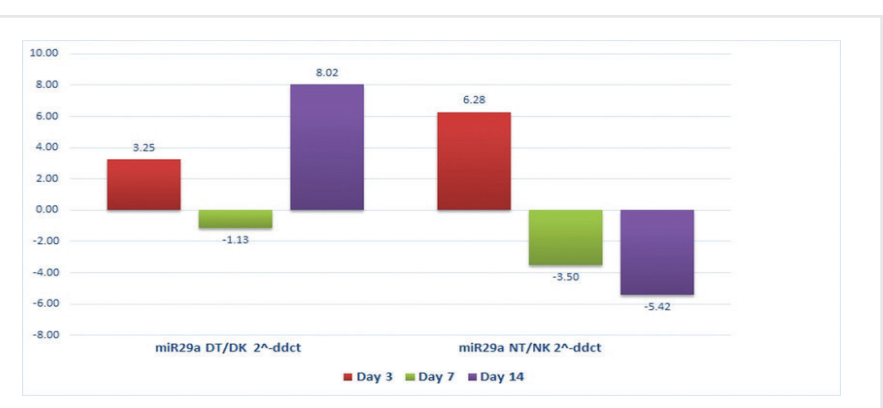

Figure 5: Evaluation of expression change of miR29a gene in the larval secretion applied wound tissue on the $3^{\text {rd }}, 7^{\text {th }}$ and $14^{\text {th }}$ days, compared to the control group. Expression of related genes is shown as fold change, and diabetic and normal groups are evaluated within themselves.

When the miR146b gene was compared with the DC group on the $3^{\text {rd }}$ day, the increase in the DT group was 8.12 times, while the increase on the $7^{\text {th }}$ day was 1.97 times and 9.79 times on the $14^{\text {th }}$ day. It was seen that the fold increase was the highest on $14^{\text {th }}$ day and the least on $7^{\text {th }}$ day. In the healthy group, the expression of miR146b in the $3^{\text {rd }}$ day increased 5.95 fold in the NT group compared to the NC group whereas it decreased 5.91 fold in the $14^{\text {th }}$ day when NT decreased 2.51 fold compared to the NC group on the $7^{\text {th }}$ day. When the days 3, 7 and 14 were evaluated in the normal group, the expression of miR146b increased most on the $3^{\text {rd }}$ day, whereas on the $14^{\text {th }}$ day it showed down regulation and the expression decreased 5.95 times (Figure 5).

The expression of miR29a showed a 3.25 fold increase in the DT group compared to the DC group on the $3^{\text {rd }}$ day, a 1.13 fold decrease on the $7^{\text {th }}$ day and an 8.02 fold increase on the $14^{\text {th }}$ day. It was observed that the maximum fold increase was at the $14^{\text {th }}$ day. In the healthy group, the expression of miR29a in the $3^{\text {rd }}$ day increased 6,28 fold in the NT group compared to the NC group, decreased 3,50 fold in NT compared to the NC group on the $7^{\text {th }}$ day, and decreased 5.42 fold on the $14^{\text {th }}$ day. When the $3^{\text {rd }}, 7^{\text {th }}$, and $14^{\text {th }}$ days in the normal group were evaluated within themselves, the expression of miR29a increased most on day 3, whereas on day 14 it decreased down by 5.42 times with down regulation.

\section{Conclusion}

It is well known that the wound healing process is a highly orchestrated series of mechanisms and biological cascades, although its complex molecular mechanisms are not yet discovered completely $(13,14)$. Recent studies indicate that miRNA levels are altered during normal skin wound healing and in pathological stages leading to wound healing defects, such as diabetes (3). Although there are a large number of miRNA species expressed in wound microenvironment during different phases of wound healing, bioinformatics studies showed that miR21, miR146a, miR146b and miR29a target the mRNAs encoding many wound healing-related proteins, all of which show critical potential in effective healing $(10,15-18)$. Also we know that high glucose levels significantly affects the expression of a large set of
miRNAs (19). Since the larvae of Lucilia sericata improves the healing process, the study of the changes in the larvae secretionsinduced miRNA expression at wound microenvironment may yield insights into understanding the molecular mechanisms that regulate wound healing and may provide new and more efficient treatment for wounds (20). Therefore, the present study was conducted to investigate the effects of the larvae secretions on wound healing in diabetic rats in relation to the expression levels of miR21, miR146a, miR146b and miR29a.

Our study is an experimental study consisting of diabetic and healthy groups. Polat et al. Have identified genes that change expression on different days during wound healing with larval secretion therapy (8). Unlike this study, in our study, the course of wound healing was followed in the diabetic rat model, and the expression of miRNAs associated with the wound healing process was investigated. Our study is very important as the first study to observe the effect of larval secretion in the diabetic rat wound model.

As a result of our research on the literature and databases, miR146a, miR146b, miR29a, miR21 have been found to be involved in various stages of the wound healing process. miRNAs are known to change expression in various phases of wound healing in both healthy and diabetic individuals. If the abovementioned effects are considered in the wound healing process of the larval saliva, larval secretion may also have effects on the expression of the miRNAs we chose in this process. Considering the fact that world-wide larval treatment is mainly chronic bleeding in diabetic individuals and the presence of positive effects, our study is important in this sense.

For this purpose, it is aimed to observe the effect of larval secretion on open wounds in diabetic and normal Wistar albino rats, and to represent the relatively open wound as the wound type, with a punch biopsy instrument, each rat, dorsal thoracic region, 3 pieces each with an equal distance of about $1 \mathrm{~cm}$ a 12 $\mathrm{mm}$ diameter epidermis and a full layer excisional wound model including the dermis. Scar tissue was removed on days $0,3,7$, and 14 after wound formation. Some of the tissues were used with real-time PCR for the purpose of carrying out expression assays of miR146a, miR146b, miR29a and miR21.

As is known, The migration of fibroblasts to the wound site facilitates the synthesis of growth factors, in which extracellular matrix synthesis takes place by migration of other cell types to the wound site. In a study by Madhyastha and colleagues, it was investigated how different miRNAs associated with cell growth and proliferation contribute to the healing of diabetic wounds (21). The expression differences of the selected miRNAs in diabetic and normal wound healing were compared, showing that miR21 expressed by fibroblasts, keratinocytes, melanocytes and inflammatory cells, had significant effects on the migration of fibroblasts to the wound area. In the same study, it was also reported that the expression of the miR21 gene varied in wound healing process. In our study, it was observed that the fold change of $\mathrm{miR} 21$ on the $3^{\text {rd }}$ day increased 42.75 times in the group treated with larval secretion compared to the untreated 
diabetic group. If the role of fibroblasts in wound healing is taken into account, observing the good course of wound healing in the diabetic group on which the larval secretion is applied is a possible outcome. In the same study, it was stated that the expression of miR21 gene changed during different days of wound healing. In our study, results supporting this finding were obtained, whereas fold change values of the expression of miR21 gene differ on days 3,7 , and 14 .

Yang and colleagues studied the $\mathrm{HaCaT}$ cell line to monitor the effect of miR21 on keratinocyte migration during wound healing and observed the change of expression of the miR21 gene in the presence of TGF $\beta 1$, which stimulates the cellular uptake of growth factors by facilitating cellular movements of monocytes, lymphocytes, macrophages, keratinocytes. The expression of miR21 increases as a result of treatment with the $\mathrm{HaCaT}$ cell line, which causes TGF- $\beta$ mediated keratinocyte migration in vitro. The same study also showed that the cause of delay in re-epithelialization is related to the down regulation of miR21. These findings suggest that the increase in expression of miR21 gene in diabetic treatment compared to diabetic control may occur as a result of TGF $\beta$ increase in the environment with the therapeutic effect of larval treatment when compared to the expression of miR21 in the third day of our study (22).

Studies have shown that miR29a is down-regulated in systemic sclerosis dermal fibroblasts, which leads to many forms of fibrosis, compared with the normal group (23).

Collagen synthesis and regulation is a very important event occurring at the maturation stage of wound healing. In healthy skin fibroblasts, miR29a directly affects collagen synthesis in the post transcriptional stage. It is also known that the synthesis of miR29a is in control of TGF-beta, PDGF-B and IL-4 in healthy skin (24). Some studies show that the miR29 family has an effect on the wound-specific cellular functions and the cytokine network $(25,26)$. Ramachandran notes that miR29a is crucial in the regulation of fibrosis, which is down-regulated in the final stage of extracellular matrix synthesis. In the same study, it is mentioned that miR29a is in the target position for many proteins required for ECM synthesis. (27).

In studies conducted by Wang and colleagues, TGF- $\beta$ increases angiogenesis by upregulating miR29a (28). In our study, expression of the miR29a gene was observed to decrease 5.42fold on day 14 in normal treatment compared to normal control. This indicates that, on the $14^{\text {th }}$ day of the normal treatment group compared to the normal control group, the angiogenesis, which is now a feature of the proliferative phase, has been completed and the the wound healing has gone to completion. begun to terminate. On day 7 , similarly to day 14 , the miR29a gene expression was 5.42 fold less than normal control in normal treatment.

Although the expression of the miR146a and miR146b genes, members of the miR146 gene family involved in regulation of immune and inflammatory responses, has been reported to change in many pathological conditions, miR146a dysregulation has also been associated with many chronic inflammatory diseases such as psoriasis and rheumatoid arthritis $(25,29)$. In our study, in the diabetic group treated with larvae compared to diabetic control, the expression of miR146a gene was observed to increase 9,79 fold on the $3^{\text {rd }}$ day, 4,11 fold on the $7^{\text {th }}$ day, and 7.45 fold on the $14^{\text {th }}$ day. This upregulation has been shown to be associated with downregulation of IRAK1, TRAF6, and other pathways associated with these genes NFkB, IL-6 and MIP2, the target genes of miR146a (30). These data suggest that secretion of larvae in the treatment of promoting wound healing in diabetics and changing the mir146a expression and appears to reduce the inflammatory response.

\section{Conclusion}

In summary, our results have shown that larval secretion in wounds formed in diabetic rats affects the expression of miRNAs associated with wound healing process.

Larval secretion therapy has been shown to increase wound healing and may reduce inflammatory response by altering the expression of miR146a in diabetics.

\section{References}

1. Blakytny R, Jude E.The molecular biology of chronic wounds and delayed healing in diabetes. Diabet Med 2006; 23: 594-608.

2. Kantharidis P, Wang B, Carew RM, Lan HY. Diabetes complications: the microRNA perspective. Diabetes. 2011; 60: 1832-7.

3. Natarajan R, Putta S, Kato M. MicroRNAs and diabetic complications. J Cardiovasc Transl Res 2012; 5: 413-422.

4. Bavan L, Midwood K, Nanchahal J. MicroRNA epigenetics: a new avenue for wound healing research. BioDrugs 2011; 25: 27-41.

5. Wang T, Feng Y, Sun H, Zhang L, Hao L, Shi C, et al. miR-21 regulates skin wound healing by targeting multiple aspects of the healing process. Am J Pathol. 2012; 181: 1911-20.

6. Abdellatif M. Roles of microRNA in wound healing In: Sen CK. Advences in wound care v.2 2012. p 109-114.

7. Wollina U, Karte K, Herold C, Looks A. Biosurgery in wound healing the renaissance of maggot therapy. J Eur Acad Dermatol Venereol 2000; 14: 285-9.

8. Mumcuoğlu KY, Özkan AT. Süpüratif kronik yaraların Maggot Debridman tedavisi. Türkiye Parazitol Derg 2009; 33: 307-315.

9. Coskunpinar E, Arkan H, Dedeoglu BG, Aksoz I, Polat E, Araz $\mathrm{T}$, et al. Determination of effective miRNAs in wound healing in an experimental Rat Model. Cell Mol Biol 2015; 61 :89-96.

10. Mann J, Mann DA. Epigenetic regulation of wound healing and fibrosis. Curr Opin Rheumatol 2013; 25: 101-7.

11. Furman BL. Streptozotocin-Induced Diabetic Models in Mice and Rats.Curr Protoc Pharmacol 2015; 70: 5.47.1-20.

12. Cheng KY, Lin ZH, Cheng YP, Chiu HY, Yeh NL, Wu TK, et al. Wound Healing in Streptozotocin-Induced Diabetic Rats Using Atmospheric-Pressure Argon Plasma Jet. Sci Rep. 2018; 8: 12214.

13. Henry G, Garner WL. Inflammatory mediators in wound healing Surg Clin North Am 2003; 83: 483-507. 
14. White ES, Mantovani AR. Inflammation, wound repair, and fibrosis: reassessing the spectrum of tissue injury and resolution. J Pathol 2013; 229: 141-4.

15. Banerjee J, Sen CK. MicroRNAs in skin and wound healing Methods Mol Biol. 2013; 936: 343-56.

16. Zhang Y, Sun X, Icli B, Feinberg MW. Emerging Roles for MicroRNAs in Diabetic Microvascular Disease: Novel Targets for Therapy Endocr Rev. 2017; 38: 145-168.

17. Mulholland EJ, Dunne N, McCarthy HO. MicroRNA as Therapeutic Targets for Chronic Wound Healing Mol Ther Nucleic Acids. 2017; 8: $46-55$.

18. Soliman AM, Das S, Abd Ghafar N, Teoh SL. Role of MicroRNA in Proliferation Phase of Wound Healing Front Genet. 2018; 9: 38.

19. Tang X, Muniappan L, Tang G, Ozcan S. Identification of glucoseregulated miRNAs from pancreatic $\{$ beta\} cells reveals a role for miR30d in insulin transcription RNA. 2009; 15: 287-93.

20. Polat E, Aksöz İ, Arkan H, Coşkunpınar E, Akbaş F, Onaran İ. Gene expression profiling of Lucilia sericata larvae extraction/secretiontreated skin wounds. Gene 2014; 550: 223-9.

21. Madhyastha R, Madhyastha H, Nakajima Y, Omura S, Maruyama M. MicroRNA signature in diabetic wound healing: promotive role of miR-21 in fibroblast migration. Int Wound J. 2012; 9: 355-61.

22. Yang X, Wang J, Guo SL, Fan KJ, Li J, Wang YL. et al. miR-21 Promotes Keratinocyte Migration and Re-epithelialization During Wound Healing. Int J Biol Sci 2011; 7: 685-90.
23. Maurer B, Stanczyk J, Jüngel A, Akhmetshina A, Trenkmann M, Brock M. et al. MicroRNA-29, a key regulator of collagen expression in systemic sclerosis. Arthritis Rheum 2010; 62: 1733-43.

24. Banerjee J, Chan Y, Sen C. MicroRNAs in skin and wound healing. Physiol Genomics 2011; 43: 543-56.

25. Sonkoly E, Wei T, Janson P, Saaf A, Lundeberg L, Tengvall-Linder M. et al. MicroRNAs: Novel Regulators Involved in the Pathogenesis of Psoriasis? PLoS One 2007; 2: e610.

26. Sonkoly E, Wei T, Pavez Loriè E, Suzuki H, Kato M, Törmä H, et al. Protein kinase C-dependent upregulation of miR-203 induces the differentiation of human keratinocytes. J Invest Dermatol 2010;130: 124-34.

27. Ramachandran KN. Protective roles of miR-29a and miR-18a in liver fibrosis. Baltimore, USA: John Hopkins University; 2013.

28. Wang J, Wang Y, Wang Y, Ma Y, Lan Y, Yang X. TGF - $\beta$ Regulated miR-29a Promotes Angiogenesis through targeting PTEN in Endothelium. J Biol Chem 2013; 288:10418-26.

29. Nakasa T, Miyaki S, Okubo A, Hashimoto M, Nishida K, Ochi M. et al. Expression of microRNA-146 in rheumatoid arthritis synovial tissue. Arthritis Rheum 2008; 58: 1284-92.

30. Roy S, Sen CK. MiRNA in innate immune responses: novel players in wound inflammation. Physiol Genomics 2011; 43: 557-65. 